\title{
Dietary Adherence in Type 1 and 2 Diabetes
}

\section{Heilig Charles $\mathbf{W}^{*}$}

Department of Medicine, University of Florida, USA

*Corresponding author: Heilig Charles W, Editor-in-Chief, Professor, Department of Medicine, University of Florida, USA, E-mail: Charles.Heilig@jax.ufl.edu Received date: November 28, 2016; Accepted date: November 29, 2016; Published date: November 30, 2016

Copyright: (C) 2016 Heilig CW. This is an open-access article distributed under the terms of the Creative Commons Attribution License, which permits unrestricted use, distribution, and reproduction in any medium, provided the original author and source are credited.

Citation: Charles HW (2016) Dietary Adherence in Type 1 and 2 Diabetes . J Diabetes Metab 7: e111. doi:10.4172/2155-6156.1000e111

\section{Introduction}

Diabetes is the most emerging and common metabolic disorder known as lifestyle diseases and it is associated with many complications such as childhood diabetes type 1 and 2 diabetes, diabetes cholesterol, endocrine system diseases, and complications of hypoglycemia. Journal of diabetes and metabolism volume $\mathrm{NO} 7$, issue 8 had published 7 research articles which deals with the study of advanced type 2 diabetes treatment, diabetes statistics, pathophysiology of diabetes, obesity and diabetes, diabetes and weight loss, diabetes for dummies, diabetic diet, diabetes and alcohol, reverse diabetes, the latest research on diabetes, diabetes lipid metabolism, medical diabetes, diabetes and metabolic syndrome.

Asmaa et al., in his article evaluated the magnesium levels and their possible association with glycemic control in children with T1DM. For the present investigation 150 children with T1DM aged between 2 and 16 years and 100 apparently healthy children aged between 2.5 and 16 years were recruited. The results of the study show that serum magnesium levels were lowered in children and adolescents with T1DM. Also they have found low serum magnesium levels association with an increased risk of poor glycemic control, potentially contributing to the early development of diabetic complications [1].

Author Wyatt et al., had tried to investigate sex and genetic dependent effects of BPA consumption on traits relevant to obesity and Type 2 diabetes in juveniles, using mice as models. The study investigations suggest that dietary BPA may exacerbate childhood obesity and its consequences, and that sex and genetic background are important determinants of the physiological impact of BPA [2].

Glintborg et al., in his article detailed about the effect of 12 month randomized treatment with oral contraceptives and metformin on glp-1 in polycystic ovary syndrome [3]. Henderson G, in his article detailed about the court of last appeal - the early history of the high-fat diet for diabetes [4]. Research article of Ramadan KS, et al, tried to evaluate the antidepressant activity of aqueous extract of SP on forced swimming test on male albino rats after four weeks treatment [5].

\section{References}

1. Asmaa MN, Samira SZ, Aliaa MM, Bassem HG (2016) The Relationship between Hypomagnesaemia and Glycemic Control in Children with Type 1 Diabetes Mellitus. J Diabetes Metab 7: 693.

2. Wyatt BS, Gooding JR, Das S, Campagna SR, Saxton AM, et al. (2016) Sexand Strain-dependent Effects of Bisphenol: A Consumption in Juvenile Mice. J Diabetes Metab 7: 694.

3. Glintborg D, Mumm H, Holst JJ, Andersen M (2016) The Effect of 12 Month Randomized Treatment with Oral Contraceptives and/or Metformin on GLP-1 in Polycystic Ovary Syndrome. J Diabetes Metab 7: 695.

4. Henderson G (2016) Court of Last Appeal - The Early History of the Highfat Diet for Diabetes. J Diabetes Metab 7: 696.

5. Ramadan KS, Farid AEH, Almarashi RMM (2016) Antidepressant-like Effects of Aqueous Extract of Salvadorapersica in Rat Model of Depression. J Diabetes Metab 7: 697. 